\title{
The Role of Indonesian National Armed Forces (TNI) in Disaster Management
}

\author{
Tugas Ratmono* \\ INAF Surgeon General, INAF \\ INAF Surgeon General Office, INAF HQ \\ Jakarta, Indonesia \\ *tugas_ratmono139@yahoo.com
}

\begin{abstract}
Natural and non natural disasters that occurred in many areas in our country nowadays the intensity have dramatically increased both quantity and quality. Loss of life, property and infrastructure damage are avoidable if the natural disasters such as earthquakes tsunami and volcanic Merapi happens. Since year of 2007 , in order to anticipate the threat of disaster, the government has established a policy with the publication of law No. 24 Provincial and Regency/ Municipality. The effort of disaster relief are not only the responsibility of BNPB/BPBD, but also are require the involvement of all government institutions, private sector and all components of society, including the involvement of Indonesian National Armed Forces (TNI) a network that spread throughout the Republic of Indonesia. Indonesian Republic which have many area which vulnerable to natural hazards is Indonesia that geographically is a region with a long history of disaster. The involvement of TNI in natural disaster management became very urgent in this area, because when disasters happen, beside as disaster victims, TNI is also as a national guard command and must ready, to assist the disaster victims. As specially in emergency response.
\end{abstract}

Keywords-management disasters, Indonesian National Armed Forces, role, emrgency response

\section{INTRODUCTION}

Historically, Indonesia is one of the countries in Asia that is susceptible to disasters, both in the form of natural disasters and non-natural disasters [1,2]. Based on data, one third of Indonesia's territory has the potential for natural disasters including volcanic eruptions, earthquakes, tsunamis, floods and landslides. This condition is a consequence of the geographical, geological, biological and hydrological and demographic conditions that exist in Indonesia [3]. Non-natural disasters also often occur, among others, in the form of inter-ethnic disputes in several areas with the background of issues of ethnicity, religion, race and customs.

As a component of the nation, the TNI is called upon to assist the government in overcoming disasters that occur in Indonesian territory. This assistance task is based on the TNI's identity as a people's army, which means that the TNI comes from the people and fights for the people. This is also in accordance with the meaning contained in "8 Wajib TNI" which is a guideline for actions for TNI soldiers, especially item 8, namely: "Being an example and pioneering efforts to overcome the difficulties of the people around him".

\section{BASE}

\section{A. Legal Foundation}

Indonesian Nationel Armed Forces engagement in disaster response Law 34/2004 [4] reformed the role of the military, reducing it to War and Military Operations Other than War (MOOTW), a component of which is disaster relief and humanitarian action. This limits the military's role in internal political affairs, but it continues to play a crucial role in disaster management.

The mandate of the Indonesian National Armed Forces (Tentara Nasional Indonesia) in disaster response is clearly stipulated in Law No. 34/2004 [4] of the Indonesian Armed Forces. In this doctrine, disaster response comes under Military Operations Other Than War (MOOTW), and includes helping to respond to the impact of natural disaster, providing displacement and delivery of relief aid, and assisting with search and rescue activities.

\section{B. Theoretical Basis}

1) Human security theory in natural disasters: An incident can be classified as a disaster if there is a victim, even though only one person is a victim. This is due to a new view of the Security Theory in which humans are used as Center of Gravity. In the implementation of development, Human Security is the main concern in state policy. The government ensures that the interests of the people are the top priority in every state policy. There are two main categories in Human Security, namely Freedom From Fear (freedom from fear) and Freedom From Want (freedom from a sense of desire). There are quite a lot of threats that can interfere with the survival and existence of Human Security. 
The UN has categorized threats to Human Security into 7 categories, namely [5]: Economic security; Food security; Health security; Environmental security; Personal security; Community security; Political security. The first four threats (economic security, food security, health security and environmental security) are classified as Freedom From Want and the next three threats (personal security, community security and political security) are classified as Freedom From Fear.

Natural disasters can be classified as non-traditional threats which can appear suddenly and disrupt human existence due to their effects. If it is related to the 7 threats mentioned above, natural disasters are categorized as factual threats to environmental security because their consequences can result in loss of life, environmental damage, loss of property and so on.

In implementing natural disaster management, the state has the greatest responsibility to ensure that every citizen is not affected by natural disasters that occur or to provide adequate livelihood security for residents affected by natural disasters. The military as part of the government has an obligation to assist the implementation of natural disaster management in accordance with the applicable mechanisms. Natural disasters are one form of non-traditional threats to Human Security. Based on this, the military is called in and participates in assisting the government in helping with natural disasters in accordance with the prevailing mechanisms.

The task of overcoming natural disasters is one of the main tasks of the TNI which is part of the duties of the Military Operation Other Than War (OMSP) as mandated in Article 7 paragraph 2 of Law No. 34 of 2004 on the TNI [4].

2) Capacity theory: Capacity can be defined as the ability of individuals and organizations or is part of the organization to perform functions effectively, efficiently and sustainably in order to achieve optimal organizational goals. Capacity is "The ability to perform appropriate tasks effectively, efficiently and sustainably" (the ability to perform tasks effectively, efficiently and sustainably).

The elements contained in the capacity consist of: Specified objectives (specific objectives); Efforts (Efforts and efforts); Capabilities (Capabilities); Resources (Resources); Work organization (work planning). Milen [6] states that capacity is "the ability of an individual, organization or system to carry out its proper functions efficiently, effectively and continuously". Furthermore, Morgan in Milen [6] defines capacity as "Ability, skills, understanding of attitudes, values, relationships, behavior, motivation, resources and conditions that enable individuals, organizations, networks / sectors and the broader system to carry out their functions and achieve the development goals that have been set from time to time "

There are three levels (levels) in the framework of development which make the focus of the analysis and process of change in an organization, namely: 1) System / policy level;
2) Organization / institution level; 3) Level of individual / human resources.

3) Disaster management theory: The objectives of disaster management include: 1) Reducing or avoiding potential losses from hazards; 2) Ensuring the delivery of assistance quickly and precisely to disaster victims; 3) Achieve fast and effective recovery. The distribution of disaster management begins with preparing preparedness before a disaster occurs, when a disaster occurs and its actions and the recovery phase which includes reconstruction and rehabilitation. Handling of disasters. Disaster management is divided into: Mitigation (mitigation), Preparedness (preparedness), Response (response), and Recovery (recovery).

Disaster management staging is divided into pre-disaster activities and post-disaster activities. The activities before the disaster are divided into: 1) Prevention; 2) Mitigation (Mitigation); 3) Preparedness (Preparedness). Activities after a disaster include: Emergency Response (Response / Relief); 2) Recovery (Recovery); 3) Rebuilding (Figure 1).

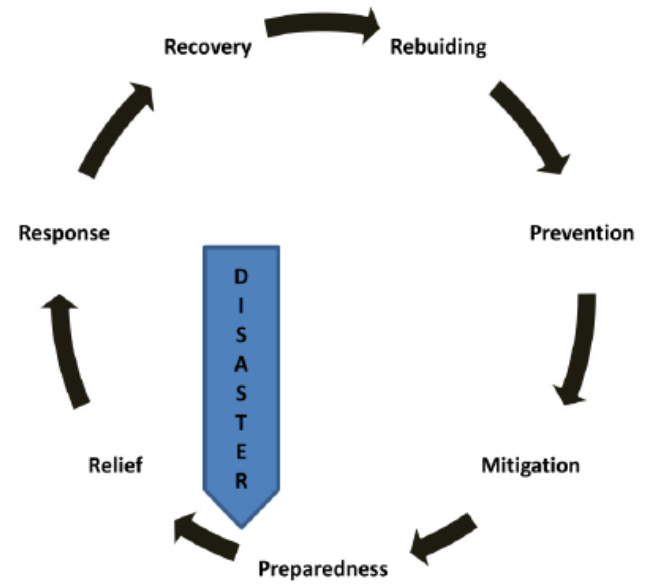

Fig. 1. Disaster management cycle.

In connection with the task of natural disaster management, the INAF (TNI) as a government apparatus is also called upon to cope with disasters that occur in accordance with the applicable mechanisms. The INAF (TNI) is involved in all phases of disaster management to assist the central government and local governments. In connection with that matter,

\section{ROLE OF INAF(TNI) IN DISASTER MANAGEMENT}

The Indonesian National Armed Forces (TNI) is mandated to respond in times of disaster and is integrated into the system at the level of fi rst response. The TNI is considered a part of the government disaster response effort and its mandate in disaster response (rather than disaster management) 109 is clearly stipulated in Law No. 34/2004 On the Indonesian Armed Forces [4]. In its doctrine, disaster response comes under Military Operations Other Than War (MOOTW) and includes helping to respond to the impact of 
natural disaster, displacement and delivery of relief aid, and assisting with search and rescue activities. Military involvement is officially activated by a request from the relevant civilian authorities. In practice, often the military will begin responding before an official request is issued and before the relevant civilian response mechanisms are in place to begin relief operations. Depending on the geographical location of a disaster and the socio-political conditions, the military may also enact an internal security mandate to maintain security. The relevant army commander will at times make this decision without waiting for a civilian directive, but once the civilian response mechanisms are in place, the military operations fall under the civilian command. The military's role as both first responder and first response mechanism is widely recognised and accepted by society as well as national and in-country international response actors. The military has significant capacity due to its unique geographical structure and substantial human resources-approximately 676,500 personnel-guaranteeing its presence throughout the country. For this reason, the military is often a fast, first response mechanism, being present at the scene of a disaster before civilian stakeholders arrive. A member of the military often will be appointed as the incident commander in the event of a disaster, to lead the area command at the provincial and district levels.

Since the 2004 Indian Ocean tsunami, efforts have been made to improve the Indonesian military disaster response capacity in the midst of a modernisation process. The socialisation of disaster management policies and delivery of training is an ongoing process, though challenging given the size and geographical spread of the military.

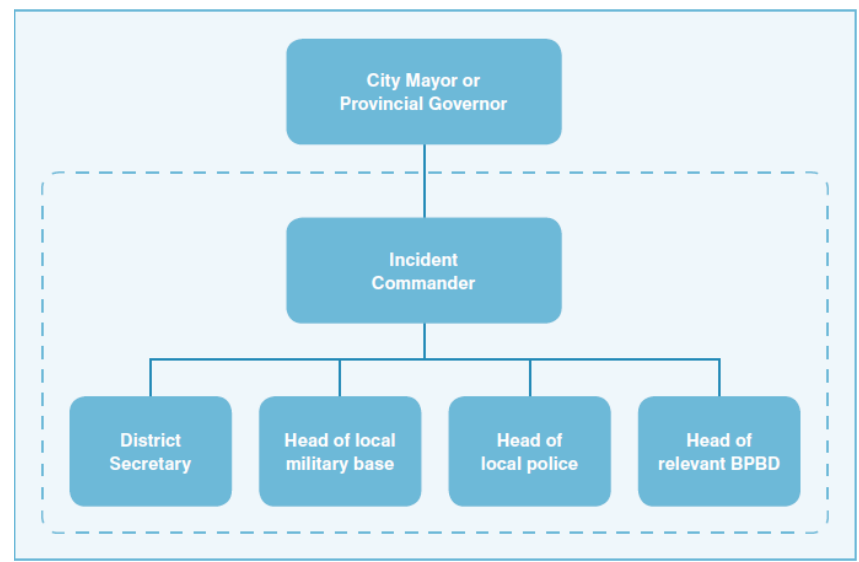

Fig. 2. Natural disaster management

Natural disaster management tasks are the responsibility of BPNB in controlling natural disaster management in Indonesia in accordance with RI Law No. 24 of 2007 [7], Presidential Regulation of the Republic of Indonesia No. 8 of 2008 dated 26 January 2008 concerning the National Disaster Management Agency (BNPB) [8] and Government Regulation of the Republic of Indonesia No. 21 of 2008 dated 28 February 2008 concerning the Implementation of Disaster Management [9] (Figure 2). The main duties of the TNI, which include helping with disaster management, are obliged to provide assistance to the central and regional governments in overcoming natural disasters that occur in close coordination with related agencies.

Disaster management is not solely the responsibility of the Government in this case civilian agencies, but also the involvement of all parties including elements of the INAF (TNI), especially with the INAF (TNI) mandate to carry out military operations other than war to cope with the consequences of natural disasters, displacement and providing humanitarian assistance. This makes the INAF (TNI) at the forefront when there is a disaster emergency in the country.

Law number 34 of 2004 [4] concerning the Indonesian National Armed Forces mandates the role of INAF(TNI) in disaster management as stipulated in article 7 paragraph 2 point 9 , namely helping local governments and point 12 , namely help cope with the consequences of natural disasters, evacuation and the provision of humanitarian assistance. The law binds the INAF (TNI) to play an active role in disaster management in Indonesia, so that it can be seen that the TNI's movements are always ahead when an emergency occurs. in Indonesia. The role of the TNI in Disaster Management is both a duty and an obligation in carrying out military operations other than war.

Stand by Force disaster management with the following characteristics: 1) equipped with a medical team, an electrical handling team, a team communication handling, fast motion team. 2) unit can deployed in a matter of hours. 3) was transported by $\mathrm{C}-139$ Hercules aircraft. 4) use TNI units as the core under the command of BNPB and under the Coordinating Minister for Human Development and Culture (PMK). The purpose of establishing Stand by Force is as a disaster management preparedness effort as one of the government's priorities in disaster management. The implementation of this order is with the formation of Rapid Response Force For Disasters (SRC PB) by BNPB. The SRC PB members themselves consist of the TNI, POLRI, Ministry of Institutions and related agencies. SRC PB is not only prepared for disaster management that occurs in Indonesia but also to assist disaster management in other countries if necessary. The competence of personnel and teams from the SRC PB must continue to be improved and always be alert in handling tasks. Not only skills improvement, utilization of modern equipment owned by BNPB but also understanding of procedures that apply at the national and international levels. SRC PB is divided into 2 regions, namely West under the coordinator of $1^{\text {st }}$ Division Kostrad Cilodong, and East Region under the coordinator of $2^{\text {nd }}$ Division Kostrad Malang (Figure 3). 


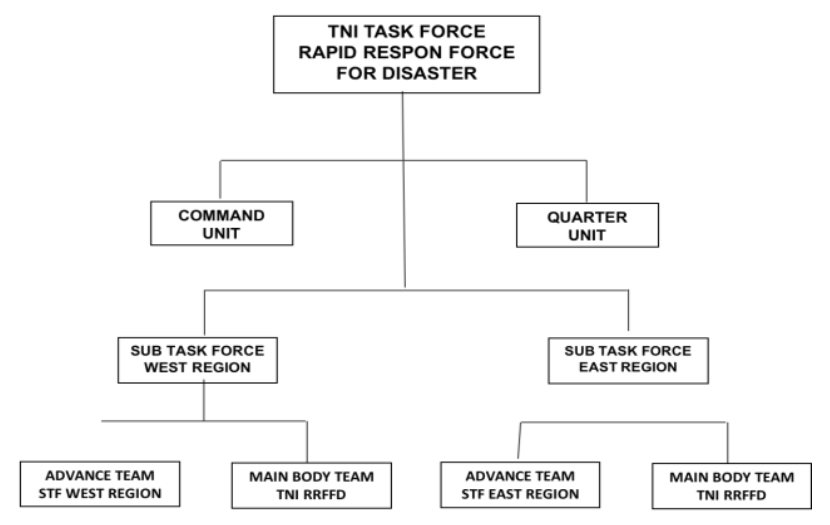

Fig. 3. Disaster emergency response command.

\section{A. The Role of the TNI in Disaster Management as Soft}

Diplomacy in an International Role.

Competency enhancement is not only prepared for disaster management, but also for the preparation of international-level Joint Exercises such as ADMM, ARF, ARDEX, DIREX, DREE and Mentawai Megathrust Rehearsal. The organizational structure of the Rapid Response Force For Disasters (SRC PB) is filled by personnel from the TNI and institutional ministries in accordance with the basic duties and competencies possessed by each ministry in question. In addition to functioning in disaster management in Indonesia, SRC PB is expected to become a humanitarian ambassador in helping other countries affected by disasters, namely as soft diplomacy, by providing assistance to countries affected by disasters, the implementation using military personnel and equipment for humanitarian purposes. For example during the tsunami in Japan on March 11, 2011, as well as when the floods in Pakistan on July 26, 2010, earthquake in Haiti on January 12, 2010, earthquake in Nepal on April 25, 2015, earthquake in Vanuatu on July 23 January 2015 and so on.

\section{B. The Role of the TNI as Incident Commander in Disaster Emergency Management}

Disaster management in Indonesia will not deny the importance of a commando figure in establishing a command post disaster emergency response. The commander of disaster emergency management needs someone who is knowledgeable and a very broad understanding of both knowledge of disasters, mastery of the field and the ability to coordinate the movement of resources. The role of the TNI as Incident Commander in Indonesia has been carried out in several major disasters including the following major disasters led by the TNI: Tsunami in Banten 22 December 2018, Earthquake, Tsunami and Liquefaction Palu on September 28 2018, Lombok Earthquake July 29 2018, handling the Covid-19 pandemic in 2020. The culture of one command and the strong spirit of the Korsa and the ease in mobilizing human resources and equipment are one of the reasons for the appointment of the
TNI as the incident commander for handling disaster emergency in several affected areas.

\section{The Role of INAF (TNI) in the Post-Disaster Phase.}

One example of the role of the TNI in this phase can be seen in the implementation of the construction of permanent housing in Siosar

victims and refugees of the eruption of Mount Sinabung in Karo Regency, North Sumatra Province. The dominant role of the TNI in the construction of permanent housing has received appreciation from the victims and the community who will occupy this permanent residence. To commemorate the services of the TNI, almost all of these permanent residential buildings paint is green in this color selection, the result of an agreement from the community so that they can commemorate the services of the TNI who have built their permanent housing.

\section{CONCLUSION}

Indoesian National Armed Forces (TNI) are mandated to respond in times of disaster and are integrated into the system at the level of fi rst response.

- TNI involvement in response operations should be activated by a request from the relevant civilian authorities, although in practice often the military begin responding before an offi cial request is issued and before the relevant civilian responding mechanisms are in place to begin relief operations

- TNI tend to become involved in disaster response and recovery and rehabilitation, but have limited involvement in planning and preparedness, although this is changing.

- The role of the TNI in disaster management both in the pre-disaster phase, disaster emergency, to rehabilitation and reconstruction is very vital and needs to be continuously involved, because in terms of knowledge of policies and substance of disaster management concepts, as well as practically in carrying out emergency activities in the TNI field have this capacity.

- Synchronization of regulations owned by the TNI and BNPB needs to be socialized to the lowest units.

- The ability that the TNI needs to have is an understanding of disaster management legislation, be it Law number 24 of 2007 or its derivatives in the form of a regulation by the head of the BNPB.

- In addition, disaster management capabilities also need to be improved both in the pre-disaster, disaster emergency and post-disaster phases.

- Technical skills such as assistance to victims, evacuation and search and rescue capabilities, management of communication and coordination with 
related agencies and understanding how to manage disaster finance also need to be improved.

\section{REFERENCES}

[1] P. Parulian, M.H. Tinambunan, S. Ginting, M.K. Gibran, A. Wanto, N. Nurmawati, and G.W. Bhawika, "Analysis of Sequential Order Incremental Methods in Predicting the Number of Victims Affected by Disasters," Journal of Physics: Conference Series, vol. 1255, no. 1, p. 012033, 2019

[2] H.A. Pritasa, "The Importance of Efforts of Managing Non-Natural Hazards In Indonesia," Proceeding Seminar Nasional STMA Trisakti, vol. 3, no. 1, pp. 1-6, 2019.
[3] BNPB Regulation No. 3/2008: Guidelines for the Establishment of BPBD. Jakarta: BNPB, 2008.

[4] Law No. 34/2004 on the Indonesian Armed Forces

[5] S.N. MacFarlane and Y.F. Khong, Human security and the UN: A critical history. Indiana University Press, 2006.

[6] A. Milen, What Do We Know About Capacity Building? An Overview of Existing Knowledge and Good Practice. World Health Organization (Departement of Health Service Provision), Geneva, 2006

[7] Law No. 24/2007 Concerning Disaster Management

[8] Government Regulation 21/2008 Concerning Disaster Management.

[9] Presidential Regulation No. 8/2008 on the Establishment of BNPB. 